\title{
Lateral
}

Journal of the Cultural Studies Association

\section{Review of The University and Social Justice: Struggles across the Globe edited by Aziz Choudry and Salim Vally (Pluto Press / Between the Lines)}

\author{
by Vineeta Singh I Book Reviews, Issue 10.1 (Spring 2021)
}

\begin{abstract}
In this edited collection, Aziz Choudry and Salim Vally present reflections and analyses from scholar-activists in education studies, anthropology, literature, and cultural studies describing university-based and affiliated social movements. Through thirteen essays covering case studies in twelve countries, the anthology offers a broad review of student organizing against neoliberalization and more specifically, the privatization of higher education; intersectional and coalitional strategies imagined through these struggles; and alternative modes of knowledge production pre-figured in their organizing. Geographic and disciplinary breadth make the anthology a welcome addition to the growing corpus of (transnational) critical university studies.
\end{abstract}

KEYWORDS austerity, social movements, student movement, university

The University and Social Justice: Struggles across the Globe. Edited by Aziz Choudry and Salim Vally. London: Pluto Press, Toronto: Between the Lines Press, 2020 pp. 260 (paperback). ISBN 978-1-77113-504-7. US List: \$26.

The Covid-19 pandemic has brought a new wave of attention to troubling trends in higher education across the globe. In many states and regions, creeping privatization and authoritarianism, combined with the anticipated economic fallout from the global health pandemic, have made already tenuous institutions even more precarious. Choudry and Vally's anthology shines a light on genealogies of struggle that many of us could use right now. The scholar-activists who have contributed to the collection trace the deep historical roots of current crises in higher education; offer examples of campaigns against austerity and state repression led by students and academics; and theorize organizing as a site and mode of knowledge production. In addition to discussing past and present struggles the authors-many of whom are veterans of student and other social justice organizingfrequently make recommendations for how to de-fetishize the labels of "student" and "education" in order to promote broad-based coalitional organizing that can address the systemic causes of intensifying privatization and censorship on university campuses. All royalties from the book are being donated to the Centre for Education Rights and Transformation at the University of Johannesburg.

Choudry and Vally open the anthology with an introduction that shares the core questions animating the texts in the collection: "What can be learned from the strategies, tactics, demands, and visions generated by student movements? What are their possibilities and 
limitations? How have these struggles resonated (or not) with other parts of society? How do current/recent movements/forms of activism relate to earlier moments in history/periods of struggle over education and society?" (6). The wide-ranging nature of these questions hints at the sweeping purview of the anthology. The geographic scope of the anthology is as broad as its intellectual sweep, addressing student movements against corporatization and privatization in the United Kingdom, Québec, Chile, Palestine, France, and South Africa; against the repression of anti-neoliberal dissent in Turkey, Chile, the United States, Mexico, and Nigeria; and, in one case in India, against the democratization of higher education. While the authors examine seemingly disparate examples across time and space, clear thematics organize these chapters: how student struggles "can catalyse or incubate wider struggles" (32); how these struggles ignore intersectional analyses at their own peril; the susceptibility of student struggles to cooptation by the agility of neoliberal governance; and the undercommoning practices that create new modes of world- and knowledge-making in struggle. As a whole, the anthology is a valuable survey of global student organizing and as a potential starting point for a relational, transnational study of the same.

Several essays focus their study on the demands and tactics of student organizing, including Lena Meari and Rula Abu Duhou's analysis of the September 2016 strike at Birzeit University in the West Bank and Julie Le Mazier's study of four national-level student mobilizations in France. Others, including Gükden Özcan's overview of two moments of post-coup organizing among Turkish academics and Rhoda Nanre Nafziger and Krystal Strong's analysis of student organizing in Nigeria, are driven more by an analysis of student movements within larger contexts of social justice organizing and broad-based state repression. But nearly all speak to the value of building what Cathy Cohen has elsewhere termed a "systems-based left analysis."-1 And all are useful in their introduction to comparative movement building.

Scholars working on or in student movements will find particularly useful Prem Kumar Vijayan's theorization of the "unruly student" (41-59)—an institutionally produced figure first incited to perform insurgency and then recruited into repressing similar expressions of discontent-as well as Asher Gamedz and Leigh-Ann Naidoo's reflections on knowledge production about, in, and through movement organizing, particularly in their meditations on reading as "a practice of dialogue and generous listening" (202) and "the editor-instruggle's role as that of an organizer" (203).

Scholar-activists in the US will also benefit from Rabab Ibrahim Abdulhadi and Saliem Shehadeh's frank account of the how the Arab and Muslim Ethnicities and Diaspora program at San Francisco State University has had to confront the deliberate entanglements of Zionism and corporatization. Abdulhadi and Shehadeh describe how populating boards of trustees with "corporate leaders, including CEOs, partners at mega law firms, foundation directors and policy analysts in non-adjacent fields" reflects and intensifies the influence of private interests in higher education (124).

The emergence of critical university studies, a field that began to coalesce in response to the anti-austerity organizing of students and academics in 2009 and 2010, has been marked by periodic calls for more transnational analyses, for deeper historical engagement with neoliberalization, and for the de-fetishization of the university as irreconcilably different from any other institution of civil society. The essays in this collection are poised to fill precisely these gaps. It's certainly possible that critical university studies scholars in the US are not the interlocutors most authors had in mind as they wrote their essays; many 
of the contributors are social scientists and work outside the literary and cultural studies fields of critical university studies specialists. Even so, this anthology as a lot to offer scholars working in critical university studies, cultural studies, and any field that values a praxis of institutional critique and modes of knowledge production that are "in but not of" the university.

\section{Notes}

1. Cathy J Cohen, "Punks, Bulldaggers, and Welfare Queens: The Radical Potential of Queer Politics?" GLQ: A Journal of Lesbian and Gay Studies 3, no. 4 (1997): 437-65. ?

\section{Author Information}

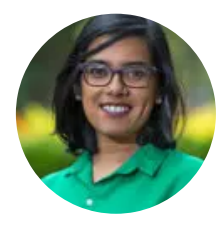

\section{Vineeta Singh}

Vineeta Singh is an Assistant Clinical Professor at the University of Maryland where she teaches and learns at the intersections of critical pedagogy; Black feminist epistemology; and critical, abolitionist, and decolonizing university studies.

View all of Vineeta Singh's articles.

\section{Article details}

\footnotetext{
Vineeta Singh, "Review of The University and Social Justice: Struggles across the Globe by edited by Aziz Choudry and Salim Vally (Pluto Press / Between the Lines)," Lateral 10.1 (2021).

https://doi.org/10.25158/L10.1.24

This content is licensed under a Creative Commons Attribution-NonCommercial 4.0 International License. Copyright is retained by authors.
}

Lateral is the peer-reviewed, open access journal of the Cultural Studies Association.

ISSN 2469-4053 